\title{
The Role of Trace Metals in Alzheimer's Disease
}

\author{
Chiara A. De Benedictis ${ }^{1}$ • Antonietta Vilella² • Andreas M. Grabrucker,3,4 \\ ${ }^{1}$ Cellular Neurobiology and Neuro-Nanotechnology Lab, Department of Biological Sciences, \\ University of Limerick, Limerick, Ireland; ${ }^{2}$ Department of Biomedical, Metabolic and Neural \\ Sciences, University of Modena and Reggio Emilia, Modena, Italy; ${ }^{3}$ Bernal Institute, \\ University of Limerick, Limerick, Ireland; ${ }^{4}$ Health Research Institute (HRI), University of \\ Limerick, Limerick, Ireland
}

Author for correspondence: Andreas M. Grabrucker, Cellular Neurobiology and Neuro-Nanotechnology lab, Department of Biological Sciences, Bernal Institute of University of Limerick, Limerick, Ireland. Email: andreas.grabrucker@ul.ie

Doi: http://dx.doi.org/10.15586/alzheimersdisease.2019.ch6

\begin{abstract}
The extracellular aggregation of insoluble protein deposits of amyloid- $\beta$ $(A \beta)$ into plaques and the hyperphosphorylation of the intracellular protein tau leading to neurofibrillary tangles are the main pathological hallmarks of Alzheimer's disease (AD). Both $A \beta$ and tau are metal-binding proteins. Essential trace metals such as zinc, copper, and iron play important roles in healthy brain function but altered homeostasis and distribution have been linked to neurodegenerative diseases and aging. In addition, the presence of non-essential trace metals such as aluminum has been associated with AD. Trace metals and abnormal metal metabolism can influence protein aggregation, synaptic signaling pathways, mitochondrial function, oxidative stress levels, and inflammation, ultimately resulting in synapse dysfunction and neuronal loss in the AD brain. Herein we provide an overview of metals and metal-binding proteins and their pathophysiological role in $\mathrm{AD}$.
\end{abstract}

Keywords: Amyloid beta; copper; iron; metal-binding; zinc

In: Alzheimer's Disease. Thomas Wisniewski (Editor), Codon Publications, Brisbane, Australia. ISBN: 978-0-646-80968-7; Doi: http://dx.doi.org/10.15586/alzheimersdisease.2019

Copyright: The Authors.

License: This open access article is licensed under Creative Commons Attribution 4.0 International (CC BY 4.0). https://creativecommons.org/licenses/by-nc/4.0/ 


\section{INTRODUCTION}

Essential trace metals and those with biological functions (biometals) play a vital role in many physiological processes in the human body. As free ion, some of them can participate in cellular signaling pathways, while bound to proteins they may have a structural or regulatory role in protein folding and function. The fact that about $10 \%$ of the genes in the human genome encode for proteins with zinc (Zn)-binding motif points to the evident dependency of biological processes on this trace metal. This number of Zn-binding proteins is not even accounting for $\mathrm{Zn}$ coordinated between two proteins in protein-protein interactions (1). In addition to $\mathrm{Zn}$, several proteins and processes depend on other essential trace metals, the most important of which are iron ( $\mathrm{Fe})$, manganese $(\mathrm{Mn})$, copper $(\mathrm{Cu})$, and selenium (Se) (a metalloid). The average human body contains about $4.2 \mathrm{~g} \mathrm{Fe}, 2.3 \mathrm{~g} \mathrm{Zn}, 0.072 \mathrm{~g} \mathrm{Cu}, 0.015 \mathrm{~g} \mathrm{Se}$, and $0.012 \mathrm{~g} \mathrm{Mn} \mathrm{(2).}$ However, the distribution of trace metals can vary depending on the organ considered. In the human brain, Fe is the most prevalent trace metal, which can be found both as heme (bound to hemoglobin in blood) and non-heme Fe. Hemebound Fe may be a major contributor to the overall concentration. Therefore, $\mathrm{Zn}$, the second most prevalent metal, may play an even more prominent role in the brain, which is underlined by its function as neurotransmitter/neuromodulator (3). Additionally, within the brain, some trace metals are enriched in particular brain regions (Figure 1). For example, the hippocampus is a brain region that is high in Zn, while the nucleus caudatus has higher levels of Fe than several other brain regions $(4,5)$. This unequal concentration of trace elements in different tissues demands a tightly regulated distribution. Given that charged molecules such as metal ions cannot freely pass the cellular membrane, a plethora of transport proteins evolved, with very specific regional and also developmentally and environmentally dependent expression. Especially, the regulation of metal concentrations in the brain faces a tight control at the level of the blood-brain barrier (BBB), a barrier composed of endothelial cells of the brain capillaries, pericytes, astrocytes, and the basement membrane (6). Together, they form a functional unit, mediating the exchange of trace metals between neurons, capillaries, and glia, while protecting against neurotoxicity of non-essential trace metals or excessive levels of essential trace elements. A specific set of transporters allows the crossing of trace metals into the brain. For example, only for $\mathrm{Zn}$, 24 different transport proteins are known in humans (7), which allow the establishment of zinc homeostasis in tissues.

The maintenance of a balance between biometals is complicated by the influence different metals have on each other. Their concentration is regulated by complex interactions between trace metal ions and their ligands. For example, due to their physicochemical nature, $\mathrm{Zn}$ and $\mathrm{Cu}$ are known to compete for the binding sites of some transporters and metal-binding proteins, resulting in an antagonistic relationship, where low levels of $\mathrm{Zn}$ increase $\mathrm{Cu}$ levels and vice versa (8). Due to these interactions, the loss of, or increase in, one trace metal can lead to the establishment of a completely new biometal profile affecting many other trace metals of a system (9).

Metal homeostasis can be challenged in many ways. In fact, our body is not only exposed to essential trace metals. Through the environment (e.g., air, food, 


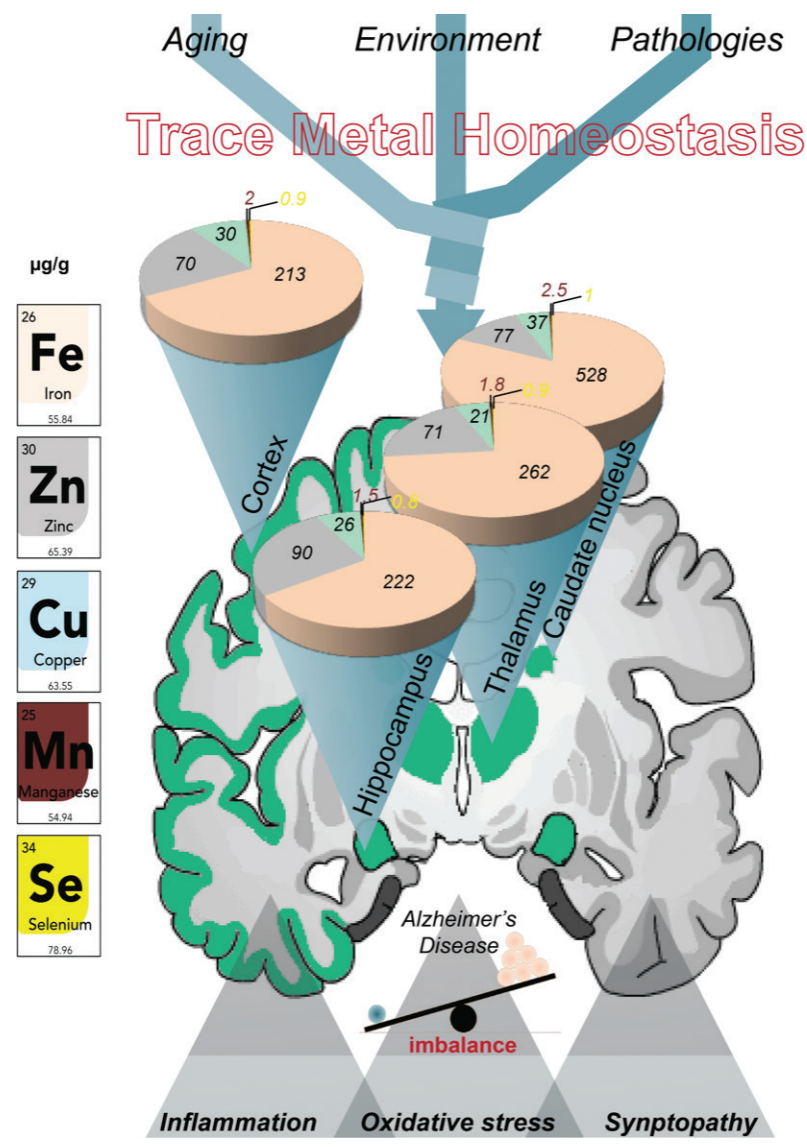

Figure 1 Trace metal concentration in different brain regions. Within the brain, trace metals are unequally concentrated in different brain regions. The figure shows the concentrations in $\mu \mathrm{g} / \mathrm{g}$ brain tissue in the human cortex, hippocampus, thalamus, and caudate nucleus for $\mathrm{Fe}, \mathrm{Zn}, \mathrm{Cu}, \mathrm{Mn}$, and $\mathrm{Se}$. This metal homeostasis can be challenged by environmental factors, the presence of pathologies such as aggregates of metal-binding proteins, and aging.

medical devices, and cosmetic products), other nonessential trace elements such as lead $(\mathrm{Pb})$, mercury $(\mathrm{Hg})$, and aluminum ( $\mathrm{Al}$ ) may enter our system. Indeed, these metals are present in all humans at low levels (e.g., $0.060 \mathrm{~g} \mathrm{Al}$, $0.012 \mathrm{~g} \mathrm{~Pb}$, and $0.006 \mathrm{~g} \mathrm{Hg}$ ). Some of these metals are currently reported to have no or little effect on the body [e.g., titanium (Ti)], while others can produce adverse effects even at concentrations slightly above the normal background levels [e.g., $\mathrm{Pb}, \mathrm{Hg}$, and cadmium (Cd)]. These toxic effects are usually due to a chemical nature similar to that of an essential metal that allows binding to metal-binding sites of metal transporters and other proteins, leading to competition with essential trace metals. However, toxic metals are often not able to produce the biological effect of essential metals, and therefore, they act antagonistically. Recent evidences put synaptic signaling, synapse formation and 
plasticity, oxidative stress, inflammation, and protein aggregation at the forefront of disease-relevant processes caused by abnormal trace metal homeostasis (Figure 1).

The enrichment of biometals in a tissue may occur through several mechanisms, such as mutations in metal import and export proteins, proteins buffering metals through transient binding (e.g. metallothioneins) (10), and also the abnormal accumulation of metal-binding proteins that occurs in several neurodegenerative diseases such as Parkinson's disease (alpha-synuclein protein) (11) and Alzheimer's disease (AD).

In $\mathrm{AD}$, a contribution of abnormal trace metal homeostasis and signaling has been extensively reported (9). However, changes in trace metals' levels in AD are complex and can rarely be directly associated with systemic alterations that can be measured in easily accessible biosamples such as serum. The most likely reason for this is the ability of senile plaques to sequester specific metal ions that in turn become mislocalized instead of decreasing or increasing systemically. $\mathrm{Cu}$, $\mathrm{Zn}$, and, to a lesser extent, Fe are known to associate with senile plaques made of beta-amyloid $(A \beta)$ protein (see below). It is hypothesized that this association causes several biological effects. For example, sequestration of $\mathrm{Cu}$ and $\mathrm{Zn}$ into plaques leads to an abnormal distribution of these metals, initially resulting in a deficiency of $\mathrm{Cu}$ and $\mathrm{Zn}$ in the vicinity of plaques $(12,13)$ and not throughout the whole brain.

Therefore, findings concerning alterations in metal ions in AD are highly dependent on the tissue and resolution used for analysis. Regarding essential metals, although results vary in some studies, $\mathrm{Mn}, \mathrm{Cu}, \mathrm{Fe}$, and $\mathrm{Zn}$ seem to show an inverse correlation with senile plaque load and thus a decrease in the cerebrospinal fluid (CSF) (14) of AD patients.

The accumulation of trace elements, including $\mathrm{Al}, \mathrm{Pb}, \mathrm{Hg}, \mathrm{Cu}$, and $\mathrm{Fe}$, has been implicated in $\mathrm{AD}$ through an increase in oxidative stress (15). In particular, a disruption in the homeostasis of $\mathrm{Cu}$ and $\mathrm{Fe}$, two redox-active metals, may increase lipid peroxidation, and the oxidative damage to neurofibrillary tangles (NFTs), senile plaques, and nucleic acids (16). Oxidative stress is induced by an imbalance in the redox state, involving the generation of excessive reactive oxygen species (ROS) or the dysfunction of the antioxidant system (17). Cu is a potent mediator of the highly reactive hydroxyl radical $(\mathrm{OH} \bullet)$ and is highly concentrated in senile plaques. Consequently, $\mathrm{Cu}$ contributes to the increase of oxidative stress in $\mathrm{AD}$. In addition, increased levels of $\mathrm{Fe}$, transferrin, and ferritin may contribute to NFT formation, possibly due to the binding of Fe to the tau protein. In the brain, oxidative stress may cause serious damage via several mechanisms, including the release of excitatory amino acids and neurotoxicity (18). Although $\mathrm{Zn}$ is redox-inert, $\mathrm{Zn}$ signaling plays a role in the regulation of proteins (e.g., enzymes kinases and phosphatases) controlling redox-signaling pathways. Therefore, while not acting as an electron donor, Zn plays a role in redox biology, where zinc, in general, is considered as an antioxidant. However, these indirect antioxidant-like effects are present only in certain conditions and both a lack and excess of $\mathrm{Zn}$ can result in pro-oxidant effects (19).

In addition to changes in trace metal homeostasis resulting from $\mathrm{AD}$, it is likely that alterations may also facilitate and trigger the development of $\mathrm{AD}$ pathology. For example, it has been shown that the levels of $\mathrm{Zn}$ decrease during 
aging as a result of more restricted food choice $(20,21)$, which may facilitate inflammatory processes (22), increase oxidative stress (19), and decrease memory as seen in several animal models for Zn deficiency (23). More importantly, key proteins involved in the etiology of $\mathrm{AD}$, and especially early-onset $\mathrm{AD}$ (familial AD), such as amyloid precursor protein (APP), presenilin 1 (PS1), and presenilin 2 (PS2), have been shown to bind to or regulate metals. For example, PS are important for cellular $\mathrm{Cu}$ and $\mathrm{Zn}$ turnover (24). Further, metals have been shown to interact with the two major disease-related proteins of AD, namely $A \beta$ and tau.

\section{METAL INTERACTIONS WITH APP}

The APP is expressed in various tissues of the human body, in particular in the brain. Its general function within the brain has been linked to neurite outgrowth and neuronal cell migration (25). However, it becomes increasingly evident that APP can be considered to act as a metalloprotein, which is involved in the regulation of $\mathrm{Cu}, \mathrm{Fe}$, and ferroxidase homeostasis (26). Recent studies indicate furthermore that metals are involved in the proteolytic processing of APP.

APP displays two putative metal-binding sides, which are located within the E1 (124-189, APP770 numbering) and E2 (376-554) domains $(27,28) . \mathrm{Cu}$ binds to APP between residues 142 and 166 (29). It has been demonstrated that the two Cu-binding residues 149 and 151 are involved in the metabolism, folding and stability, and homodimerization of APP (30). Besides, $\mathrm{Cu}$ ions have been shown to promote cell surface localization of APP (31). Furthermore, it has been shown that cellular $\mathrm{Cu}$ levels can influence the expression of APP in vitro at both gene and protein levels (32).

APP also displays an evolutionary conserved Zn-binding site between amino acid positions 170 and $188(33,34)$. The binding of $\mathrm{Zn}$ to APP has been reported to play a similar role as $\mathrm{Cu}$-binding in the homodimerization of APP (35) (Figure 2A).

Fe is involved in the direct regulation of APP translation. The APP mRNA displays an Fe response element (IRE) in its 5'-untranslated region (5'-UTR) sequence (36), and APP levels increase after a rise in cytosolic free Fe levels (37). Additionally, APP has been suggested to be involved in Fe export in the brain through the stabilization of ferroportin (Fpn). Deletion of APP in vitro in primary neurons impairs Fe export, which can be fully restored by the addition of APP (38).

$A \beta$ is derived from APP by the sequential proteolysis by $\beta$ - and $\gamma$-secretases. Metals have also been shown to indirectly influence $A \beta$ generation by modifying the proteolytic processing of APP (28). Interestingly, all three secretases $(\alpha, \beta$, and $\gamma)$ involved in the enzymatic cleavage of APP interact with metal ions. The enzymatic activity of the $\alpha$-secretase TACE is regulated by a "cysteine switch" motif, which is based on an intramolecular bond between cysteine (Cys) and a $\mathrm{Zn}$ atom in its catalytic site (39). Furthermore, the major $\beta$-secretase involved in APP processing displays a $\mathrm{Cu}$-binding site in its $\mathrm{C}$-terminal domain (40). Further, $\mathrm{Zn}$ has been shown to enhance the synthesis of PS1, the active subunit of the $\gamma$-secretase (41). 

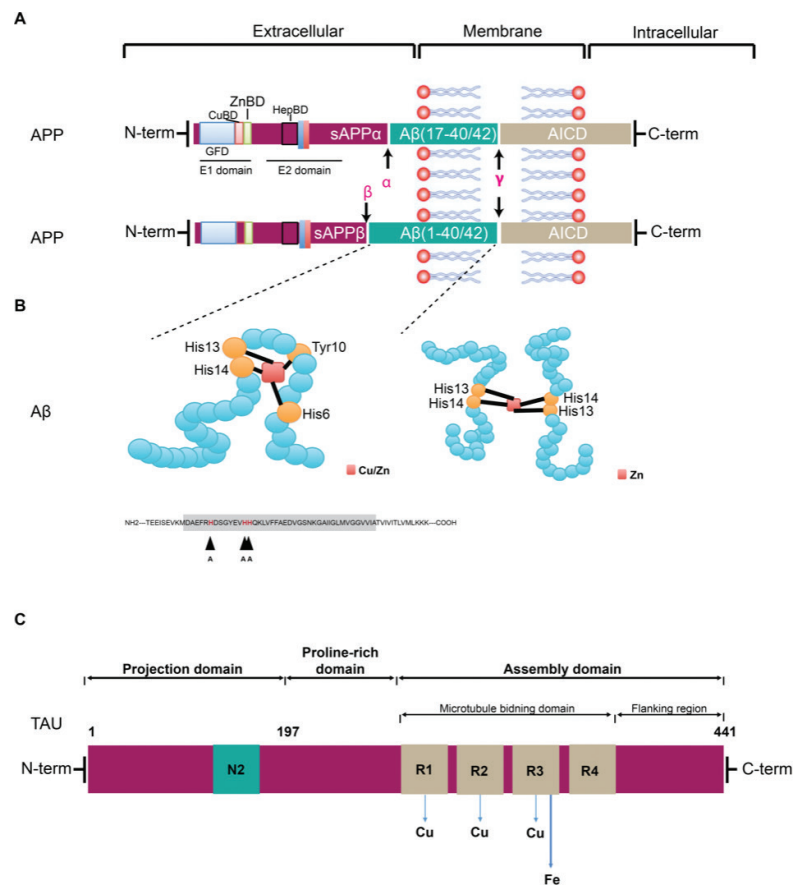

Figure 2 APP cleavage and APP and tau metal-binding sites. A) Cleavage of APP by $\alpha$ - and $\gamma$-secretases creates the sAPP $\alpha$ and $A \beta_{17-40 / 42}$ fragments (upper panel). Cleavage by $\beta$ - and $\gamma$-secretases creates the sAPP $\beta$ and $A \beta_{1-40 / 42}$ fragments (lower panel). The $\mathrm{N}$-terminal part of APP contains a CuBD, copper-binding domain; ZnBD, zinc-binding domain; HepBD, heparin-binding domain; GFD, growth factor-like domain. B) Two of several possibilities of metal interaction with $A \beta$. Below: Sequence of $A \beta, 3$ His in the $A \beta$ peptide domain of human wild type (wt) $A \beta$ are important for metal coordination. C) Representation of the three main domains studied in tau protein. The picture shows the binding sites of $\mathrm{Cu}$ and $\mathrm{Fe}$, respectively, through $\mathrm{R} 1, \mathrm{R} 2$, and $\mathrm{R} 3$ regions in the MTB ensuring the binding to the microtubules.

\section{METAL INTERACTIONS WITH AMYLOID-BETA (A $\beta)$}

The A $\beta$ domain of APP is another region that can directly bind $\mathrm{Zn}$ and $\mathrm{Cu}$ ions; however until now, there is no evidence that this region interacts with metal ions prior to the enzymatic cleavage mediated by $\alpha-, \beta$-, and $\gamma$ - secretases (42) (Figure 2B).

Aggregation of $A \beta$ into insoluble fibrils is a key pathological event in $A D$ and is mediated by the interactions of $A \beta$ with metals, in particular, $\mathrm{Zn}, \mathrm{Cu}$, and $\mathrm{Fe}$. Early studies have shown that in particular, the histidine (His) residues in $A \beta$ are responsible for the metal-mediated aggregation of $A \beta$ (43). Interestingly, in mice and rats, the same His residues are not present, which might explain why these animals are more resistant to the amyloid pathology compared to other mammals (44). 
The strong chelation properties of $\mathrm{A} \beta$ of $\mathrm{Zn}, \mathrm{Cu}$, and Fe explain the enrichment of these ions in amyloid plaques and suggest that one potential pathological influence of $\mathrm{A} \beta$ might be to sequester metal ions (45) and, through increasing concentrations of redox-active $\mathrm{Cu}$ and $\mathrm{Fe}$ ions in amyloid plaques, to promote oxidative stress.

\section{Zinc and Amyloid-Beta}

$\mathrm{Zn}$ is a factor contributing to the neurotoxicity of $\mathrm{A} \beta$ through the stabilization of amyloid fibrils (46). Various coordination sites have been proposed for the binding of zinc to $A \beta$ with particular importance of His 13 and His6. In vitro studies demonstrated that $\mathrm{Zn}$ induces the rapid and extensive aggregation of synthetic $A \beta(34,47)$, which might act as a seeding factor in the formation of amyloid plaques. In support of these studies, high levels of $\mathrm{Zn}$ have been found in the senile plaques of postmortem tissue of AD patients (45) and plaques of genetic AD mouse models. Interestingly, $A \beta$ deposits fail to develop into mature plaques in the cerebellum where vesicular $\mathrm{Zn}$ is absent. Scavenging of $\mathrm{Zn}$ ions through $\mathrm{A} \beta$ may itself be a pathomechanism of $\mathrm{AD}$. A locally decreasing $\mathrm{Zn}$ level in the vicinity of plaques contributes to synapse loss (13).

\section{Copper and Amyloid-Beta}

Homeostasis is fundamental for all metal ions, but for $\mathrm{Cu}$ it is critical because this metal is redox-active and can catalyze and activate $\mathrm{O}_{2}$, generating reactive oxygen species (ROS) involved in oxidative damage. The soluble monomeric A $\beta$ displays three high-affinity His Cu-binding sites (His6, His13, and His14), which along with the N-terminal amino group and aspartate form a tetragonal complex with $\mathrm{Cu}$ ions $(48,49)$. $\mathrm{Cu}(\mathrm{II})$ has been demonstrated to play a crucial role in the formation of $\beta$-sheet structures, which are thought to be a preliminary step of the toxic aggregates of the fibrillar form of $A \beta$. Thus, $\mathrm{Cu}$ binding to $A \beta$ has been proposed to play a major role in the neurotoxicity of $A \beta$. In line with this, a series of studies have reported that $\mathrm{Cu}$ chelators rapidly induce the inhibition of $\mathrm{A} \beta$ accumulation in transgenic $\mathrm{AD}$ mouse models $(50,51)$.

\section{Other essential trace metals and Amyloid-Beta}

Because of $\mathrm{Fe}^{3+}$ hydroxide species precipitation, the binding of $\mathrm{Fe}^{3+}$ to $\mathrm{A} \beta$ seems implausible. Instead, Asp1, Glu3, and the three His residues (His6, His13, and Hisl4) are involved in binding of $\mathrm{Fe}^{2+}$. However, iron mineral deposits in the cortical tissue may occur in vivo and contain magnetite $\left(\mathrm{Fe}_{3} \mathrm{O}_{4}\right)$. They have been found in tissue extracted from human AD brain and brain from APP/PS1 transgenic mice (52). The aggregation state of $A \beta$ appears to affect iron redox cycle and consequently may lead to the release of free radicals via Fenton chemistry. Interestingly, the degree of altered iron accumulations in $\mathrm{AD}$ is correlated with the amount of $A \beta$ plaque pathology. However, these changes appear to occur after the development of the AD pathological hallmarks (53). Increased aggregation of 
$A \beta$ has been observed through the down-regulation of the enzymes that regulate the degradation of extracellular A $\beta$ deposits induced by high Mn levels (54).

\section{Toxic trace metals and Amyloid-Beta}

Several studies have suggested that $\mathrm{Al}$ interacts with $\mathrm{A} \beta$. Al has been detected in both the A $\beta$ plaques and NFTs. Treatment of neuronal cultures with Al resulted in a marked accumulation of $A \beta$ aggregates in vitro. However, the relevance of this for AD pathology in vivo is currently not well understood (48). Similarly, $\mathrm{Hg}$ exposure has been shown to promote the accumulation of $A \beta$ deposits in vitro. $\mathrm{Cd}$, like $\mathrm{Mn}$, has been reported to reduce the expression of $\mathrm{A} \beta$-degrading enzymes, resulting in an increased $A \beta$ accumulation(48).

\section{METAL INTERACTIONS WITH TAU}

In $\mathrm{AD}$, Tau aggregates due to hyperphosphorylation, abnormal splicing, or mutation in the tau encoding gene $(55,56)$. AD is the most common tauopathy among degenerative brain diseases. The tauprotein, with a molecular weight between 50 and $68 \mathrm{kDa}$, is encoded by a single gene (MAPT) located on chromosome $17 q 21$ in humans. Tau is mainly localized in neuronal axons, but also dendrites (57), in the central nervous system (CNS). Tau is a microtubule-associated protein (MAP) implicated in the stabilization and integrity of microtubules (MT) in neurons, and its activity is regulated through a phosphorylation-dependent mechanism (58). In physiological conditions, tau is phosphorylated (facilitating the disassociation of the protein from the MT) and dephosphorylated (promoting the binding with MT) through the activity of tau kinases and phosphatases (59). In the human brain, under developmental control, six different isoforms of tau exist with a variation in size from 352 to 441 amino acids. The isoforms differ in the inclusion or exclusion of $\mathrm{N}$ repeats $(0 \mathrm{~N}$ or $1 \mathrm{~N}$ or $2 \mathrm{~N}$ ) at the amino-terminal region and for the presence of three (3R) or four (4R) MT-binding domain (MTB) repeats $(\mathrm{R})$ in the carboxyl-terminal part of the molecule (60).

The major domains identified in the tau protein are the projection domain, situated in the acidic N-terminal part, and the assembly domain, localized in the basic C-terminal domain. The two domains with the opposite charge are separated from one another by the proline (Pro)-rich region, situated in the middle part of the protein. Here, tau interacts with proteins containing an SH3 domain. Further, the Pro-rich region is the target of different Pro-directed kinases and also FYN-tyrosine kinases (61). The assembly domain, through R1-R4 repeat regions and flanking domain, binds microtubules and supports their assembly. This domain is the key in the regulation of the phosphorylation state of the tau protein (62). On the contrary, the projection part does not interact with microtubules but projects away from their surface interacting with other cytoskeletal elements, mitochondria or the neuronal plasma membrane $(63,64)$.

Phosphorylation of tau plays a crucial role in the pathogenesis of $\operatorname{AD}(65,66)$ introducing negative charge(s) that promote an electrostatic interaction with metal ions (67) (Figure 2C). Tau abnormal phosphorylation leads to an abnormal structure, that is, polymerized into paired helical filaments (PHFs) which may further 
aggregate to form NFTs, assuming the shape of a toxic protein deprived of the biological functions typical of the MAP family. It was reported that in AD brains, NFTs include metals, confirming an association between endogenous redox-active transition metals and metal-binding sites in tau (68). Binding of a series of metal ions including the essential biometals, $\mathrm{Zn}, \mathrm{Cu}, \mathrm{Fe}, \mathrm{Mg}$, and $\mathrm{Mn}$, and non-essential trace metals, $\mathrm{Pb}, \mathrm{Cd}, \mathrm{Hg}$, and $\mathrm{Al}$, may promote tau hyperphosphorylation and induce tau aggregation. In contrast, $\mathrm{Fe}$ and lithium (Li) reduce the abnormal phosphorylation of tau (48). For this reason, biometal homeostasis is essential, and the disruption of this balance may play a key role in the pathogenesis of $\mathrm{AD}$.

\section{Zinc and Tau}

A disruption in the $\mathrm{Zn}$ homeostasis leads to a series of pathogenic conditions in the AD brain, including the formation of NFTs composed of hyperphosphorylated tau. Recent studies show that $\mathrm{Zn}$ is involved in the mechanism of tau hyperphosphorylation via two different interactions: in vitro, Zn can directly affect tau at serine (Ser) and Pro sites, at threonine (Thr) and Pro sites or via two Cys residues: C291 and C322 (69). At the same time, Zn can indirectly hyperphosphorylate tau protein, by activating kinase and phosphatase pathways, for example activating Raf/mitogen protein kinase and inhibiting phosphatases such as PP2A $(70,71)$.

These two independent ways of action have different effects on tau toxicity. It has been demonstrated that the direct interaction between tau and Zn plays an important role in tau toxicity: after removing the Zn-binding site, tau toxicity is completely abolished, assuming that the toxic effect of tau necessitates both the presence of hyperphosphorylation and Zn bond. Tau hyperphosphorylation pathways appear to be less toxic, compared to tau toxicity that occurs from the direct binding between tau and $\mathrm{Zn}$ (72). Recently, it has been discovered that Zn could be considered a catalyst, accelerating the aggregation of tau-R3 complexes and, at the same time, promoting the formation of tau oligomers $(73,74)$. Thus, correct $\mathrm{Zn}$ homeostasis in $\mathrm{AD}$ is fundamental because abnormally high concentrations of this mineral induce the development of granular tau aggregates, while abnormally low concentrations of $\mathrm{Zn}$ lead to amyloid fibril formation (75).

\section{Copper and Tau}

A high concentration of $\mathrm{Cu}(0.4 \mathrm{mM})$ was reported in amyloid plaques and NFTs. Thereby, NFT may be linked to high levels of redox-active $\mathrm{Cu}$ (68). Besides, $\mathrm{Cu}$ is involved in tau hyperphosphorylation by activating the cyclin-dependent kinase (CDK)5/p25 complex. Tau hyperphosphorylation resulting from the activation of GSK-3 $\beta$ kinase by $\mathrm{Cu}$ is controversial: some studies suggest that GSK-3 $\beta$ kinase is activated by $\mathrm{Cu}(76,77)$, while other studies propose that GSK-3 $\beta$ kinase may not necessarily be involved in the abnormal phosphorylation of the protein (78). The binding between tau and $\mathrm{Cu}$ is highly selective. Studies revealed that the fulllength Human Tau40 isoform (K32) can bind one $\mathrm{Cu}$ for each monomer (1:1 binding stoichiometry) with a dissociation constant $\left(K_{d}\right)$ close to $1 \mu \mathrm{M}$ via two Cys residues. The sequences mediating the binding of $\mathrm{Cu}$ are ${ }^{287}$ VQSKCGS ${ }^{293}$ and ${ }^{310}$ YKPVDLSKVTSKCGS ${ }^{324}$. An analysis conducted by circular dichroism and nuclear magnetic resonance (NMR) spectroscopy showed only limited formation 
of aggregates after binding $\mathrm{Cu}$ because the addition of $\mathrm{Cu}$ to K32 does not affect the secondary structure, and thus, tau remains mostly disordered (79). In vitro, it has been demonstrated that $\mathrm{Cu}$ can bind different tau fragments containing diverse MTBR such as R1 and R2, showing alterations in the secondary structure $(80,81)$. Furthermore, the interactions between tau R2 and $\mathrm{Cu}$ lead to the production of $\mathrm{H}_{2} \mathrm{O}_{2}$ (82). The repeat $\mathrm{R} 3$ can be associated with more than one $\mathrm{Cu}$ ion via two His residues (83).

The role of $\mathrm{Cu}$-binding to tau remains controversial, although some studies suggest that the binding between $\mathrm{Cu}$ and tau inhibits the formation of abnormal aggregates in vitro $(78,81)$. For example, increasing intracellular $\mathrm{Cu}$ levels by the addition of $\mathrm{Cu}$-bis (thiosemicarbazone) complexes, inhibits tau hyperphosphorylation (76).

\section{Iron and Tau}

Fe dysregulation is linked to oxidative stress in tauopathies. Fe, as $\mathrm{Zn}$ and $\mathrm{Cu}$, interacts with some of the isoforms of the tau protein, causing irreversible structural changes. The result of this interaction is protein aggregation and/or oxidative stress, through the Fenton reaction, perpetuating a condition of cellular damage. Analysis of postmortem AD brains shows increased Fe levels in several brain regions (84).

In the human body, $\mathrm{Fe}$ is available in two oxidation states: $\mathrm{Fe}^{3+}$ (redox-inert state) that is stored in ferritin and $\mathrm{Fe}^{2+}$ (redox-active). The iron status associated with NFTs in $\mathrm{AD}$ is $\mathrm{Fe}^{3+}$, which can induce the aggregation of hyperphosphorylated tau. Fe-binding sites using His residues have been identified in tau (85). The hyperphosphorylated status of tau may not involve $\mathrm{Fe}^{3+}$ interacting with the protein, but Thr phosphorylation can regulate the interaction between tau and $\mathrm{Fe}^{2+}(86)$. Thus, the phosphorylation level of tau causes conformational changes of tau to mediate tau-Fe interactions (87). In addition to a direct interaction, Fe induces tau hyperphosphorylation, both in vitro and in vivo, by activating the CDK5/p25 complex and GSK-3 $\beta$ and MAP kinases (88). This evidence suggests a possible role of iron involved as a co-factor for tau aggregation.

\section{Other essential trace metals and Tau}

In AD patients, Mg levels appear lower (540-625 $\mu \mathrm{g} / \mathrm{g}$ ) compared to the physiologic range $(620-680 \mu \mathrm{g} / \mathrm{g})(89)$. In vivo, data obtained from an AD transgenic mouse model show that Mg increases the phosphorylation of the GSK-3 $\beta$ kinase at Ser9, which in turn reduces the hyperphosphorylation of tau protein (90). Additionally, in postmortem brains of patients affected by AD, the level of Mn appears to be higher (91). An increase of Mn levels is related to abnormal tau aggregation and its hyperphosphorylation, mediated by GSK-3 $\beta$ kinase (92).

\section{Toxic trace metals and Tau}

$\mathrm{Al}$ is the most widely exogenous metal ion distributed in the environment. As $\mathrm{Fe}^{3+}, \mathrm{Al}^{3+}$ is a trivalent cation that influences protein phosphorylation of tau $(93,94)$. Recent data show that Al can promote the formation of sodium dodecyl 
sulfate (SDS)-resistant tau oligomers after tau phosphorylation (95). The role of $\mathrm{Al}$ in $\mathrm{AD}$ has been intensively investigated since NFT-like deposits were discovered in mammalian brains after intracerebral Al injection (96). Al has been shown promoting tau aggregation through the down-regulation of PP2A activity and an increase of CDK5 and GSK-3 $\beta$ kinase levels (97). Thus, Al, although not directly binding to tau, may have a role as co-factor in AD (98).

Further, heavy metals such as $\mathrm{Cd}, \mathrm{Pb}$, and $\mathrm{Hg}$ have been implicated in $\mathrm{AD}$ pathology (99). Data show that $\mathrm{Cd}$ is involved in the formation of NFTs (100, 101). Both in cell models and in in vivo studies, Cd increases the activation of GSK-3 $\beta$ kinase, causing the hyperphosphorylation of tau (102). Similarly, Pb has been reported to modulate tau aggregation by increasing the activity of CDK5/p25 complex and GSK-3 $\beta$ kinase (103). Hg was demonstrated to inhibit tubulin that has a very high-affinity binding-site for $\mathrm{Hg}$ (104). Once $\mathrm{Hg}$ binds tubulin, the structural integrity of the protein is impaired. The final result of this interaction between $\mathrm{Hg}$ and tubulin is the formation of NFTs (105). Also, Hg is involved in tau hyperphosphorylation; the mechanism starts with the oxidative stress induced by $\mathrm{Hg}$, ultimately affecting tau phosphorylation status (106).

\section{OTHER METAL-BINDING PROTEINS AND THEIR ROLE IN AD}

Several of the effects of an altered trace metal status in AD such as increased oxidative stress, neuroinflammation, and effects on synapses are mediated by excess or lack of trace metals for binding to proteins other than $A \beta$ and tau. Together with several other factors in AD, oxidative stress leads to an activation of the immune system. The immune system is highly dependent on trace metal biology. Especially, Zn signaling seems to be a key mediator of inflammatory responses. For example, the activity of NF-кB (nuclear factor kappa-light-chain-enhancer of activated B cells), a major regulator of pro-inflammatory cytokines such as interleukins (IL) (107), is regulated, among others, by $\mathrm{Zn}$ through $\mathrm{Zn}$ binding of the IKK (IKB kinase) complex member IKK $\beta$ (108). Further, the formation of senile plaques made of A $\beta$ aggregates stimulates inflammasomes, such as the NLRP3 (nucleotide-binding domain and leucine-rich repeat-containing family, pyrin domaincontaining-3) inflammasome that detects the inflammatory $A \beta$ aggregates and responds by forming active IL-1 $\beta$ through secreting caspase-1 (Casp-1) (109). IL-1 $\beta$ acts as an inflammatory cytokine (110), which leads to the creation of an inflammatory environment around the plaque. This ultimately decreases plaque degradation and destruction by microglia cells. Zn deficiency and/or high Cu levels facilitate NLRP3 inflammasome activation (111) and thereby the production of IL-1 $\beta$ in macrophages (112).

Initially, Pro-IL-1 $\beta$ is expressed in response to damage-associated molecular patterns (DAMPs) that bind to pattern recognition receptors (PRRs) on the macrophage to upregulate pro-inflammatory gene expression. Inflammation, protein misfolding, and aggregation, as well as neurodegeneration, lead to increased levels of so-called alarmins or DAMPs that include several cytokines including those from the S100 family. The S100 proteins are engaged in classical calcium-activated signaling but recent work has shown their involvement in new biochemical mechanisms in the brain related to the prevention of protein aggregation (113) and 
sensing of neuronal $\mathrm{Ca}$ and $\mathrm{Zn}$ levels (114). Therefore, S100 alarmins are implicated in the maintenance of protein homeostasis (proteostasis) and metal ion homeostasis (metallostasis) in the brain. Upon activation and at high $(\mu \mathrm{M})$ concentrations, S100 proteins act as extracellular cytokines via RAGE (receptor for advanced glycation end-products) mediated signaling. RAGE persistent engagement increases S100 extracellular levels via NF-kB activation resulting in a positive feedback cycle (115). Glial S100B and S100A9 proteins show increased expression in response to several risk factors for $\mathrm{AD}$, including aging (116). Interestingly, S100B undergoes metal-binding-induced conformational changes and thereby delays the onset of $A \beta$ aggregation by interacting with $A \beta_{1-42}$ monomers inhibiting primary nucleation (113). However, high levels of S100B can elicit alterations in intracellular Zn concentrations (114).

The increase in $\mathrm{S100B}$ proteins and accumulation of $A \beta$ as a factor for trace metal imbalances also has direct effects on Zn signaling at excitatory glutamatergic synapses. It has been shown that the dynamics of major postsynaptic scaffold proteins of these synapses (SHANK2 and SHANK3) are dependent on Zn availability (117). Studies have shown that SHANK platform disassembly is linked to the molecular pathology of $\mathrm{AD}(118,119)$, and recent research confirmed that the progressive accumulation of $A \beta$ results in decreased $\mathrm{Zn}$ concentrations at the synapse, which in turn leads to disruption of SHANK3 scaffold formation, and ultimately, loss of synapses (13). Thus, Zn sequestration by protein aggregates in AD may be a contributor to the cognitive impairments caused by the loss of synapses through trapping synaptic $\mathrm{Zn}$ rather than through neurodegeneration in general (120). In addition, NMDA receptors at synapses are Zn-binding proteins (121). Increased trapping of $\mathrm{Zn}$ lowers the inhibitory activity of $\mathrm{Zn}$ on the NMDAR. Excessive stimulation of receptors at the excitatory synapse has been linked to neuronal death through excitotoxicity leading to chronic neurodegeneration in AD (122). Together, these metal-imbalance-driven signaling pathways create a vicious cycle leading to increased inflammation, oxidative stress, and neuronal damage (Figure 3).

\section{METAL DETECTION FOR AD DIAGNOSIS}

Several metal bioimaging strategies have been developed not only to examine the distribution of metals in human clinical AD brain tissue and AD mouse models but also to diagnose and monitor the progression of AD (123). In the clinical setting, the most common imaging tool is magnetic resonance imaging (MRI). This technique focuses on Fe due to its magnetic properties and its abundance in the brain. The latest MRI technology provides sufficient resolution to detect regional differences and has the major advantage that it can be applied to living patients rather than being a tool for postmortem analysis only (124). The presence of localized Fe can be detected by MRI (T2). However, although detecting general metal dyshomeostasis, MRI has limitations in visualizing metal-loaded plaques directly with high resolution. Further development of metal-based compounds or compounds visualizing metal homeostasis, such as a Cu-64-labelled-bis (thiosemicarbazonato) complex for clinical application in positron emission tomography (PET), and improvement of imaging devices may lead to more precise 


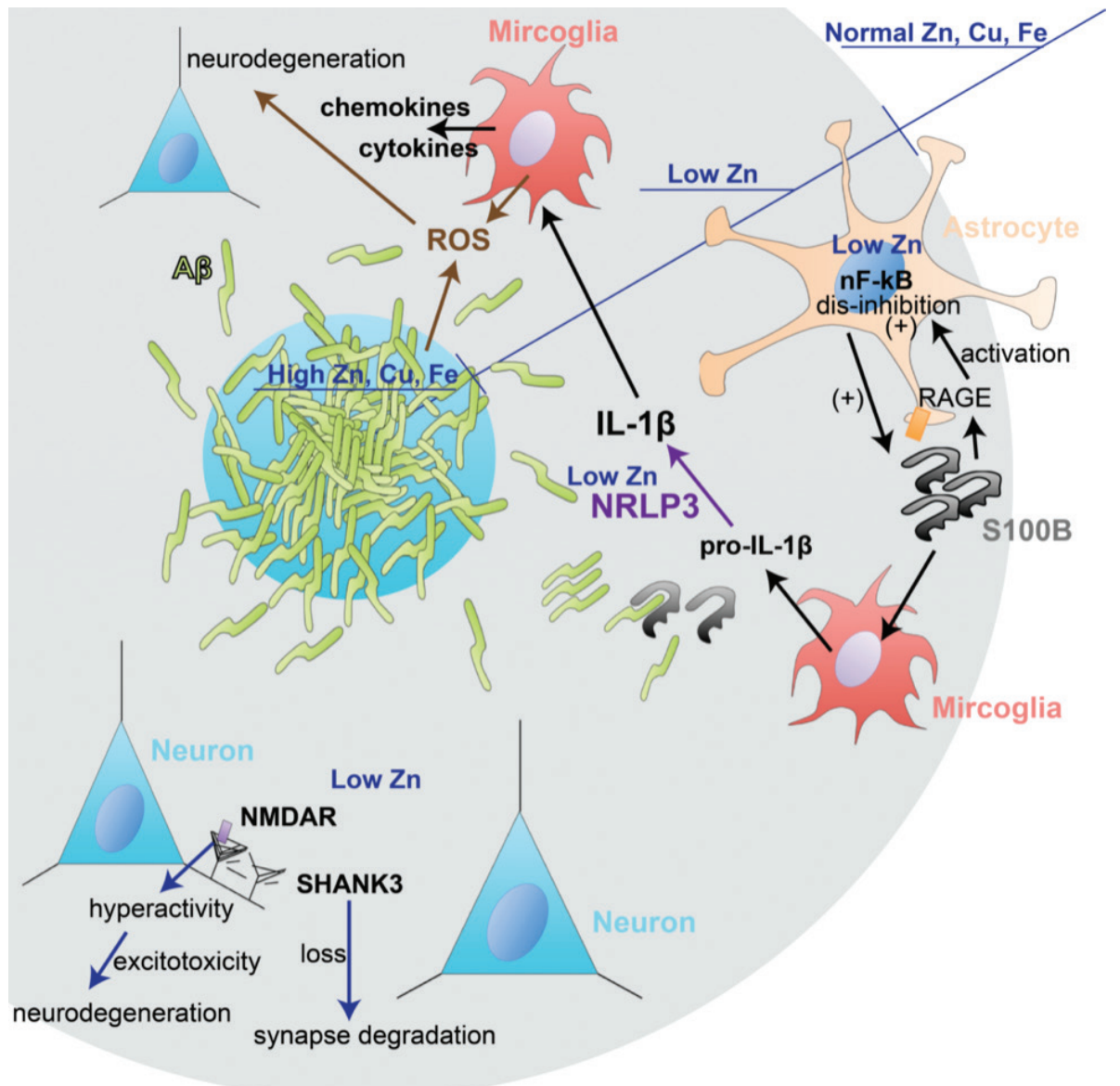

Figure 3 Interaction between $\mathbf{A} \boldsymbol{\beta}$ plaques, glial cells and trace metals. Senile plaques sequester large amounts of $\mathrm{Zn}, \mathrm{Cu}$, and Fe, creating a zone of metal depletion, especially Zn depletion, in their vicinity. While high levels of $\mathrm{Cu}$ and Fe at the center of plaques may contribute to the generation of ROS and damage neurons through oxidative stress, Zn deficiency in a zone surrounding plaques will lead to further effects: Accumulation of $A \beta$ aggregates leads to the release of S100B from astrocytes. S100B as DAMP can initially prevent A $\beta$ aggregation. However, S100B signals back to astrocytes via RAGE receptor activation that will, in turn, activate NF-kB. Active NF-kB is dis-inhibited by low levels of $\mathrm{Zn}$ and thus results in further production of S100B, which enters a positive feedback cycle. High levels of S100B further deplete $\mathrm{Zn}$ through $\mathrm{Zn}$ binding. In response to high DAMP levels (S100B), microglia cells will produce pro-IL-1 $\beta$. This will be cleaved by Casp-1-dependent processes through the NLRP3 inflammasome. NLRP3 activity is further increased by low Zn levels. Production of IL-1 $\beta$ leads to further generation of ROS and release of cytokines and chemokines from microglia cells that facilitate NFT formation and neurodegeneration. Further, low Zn levels facilitate excitotoxicity through dis-inhibition of NMDAR signaling, and low levels of Zn destabilize the postsynaptic Shank3 scaffold resulting in synapse loss. 
diagnosis and monitoring of progression and therapeutic effects based on the role of trace metals in $\mathrm{AD}$ in the future (124).

\section{METALS HOMEOSTASIS AS A THERAPEUTIC STRATEGY FOR AD}

Based on the interactions of metals with several key proteins of the AD pathology, different therapeutic approaches aimed at restoring or manipulating metal homeostasis and, thereby, regulating oxidative stress, tau phosphorylation, A $\beta$ aggregation, and inflammation have been developed in the last decade.

For example, metallothionein 3 (MT-3), a key regulator of metal homeostasis in neural tissue, has been found down-regulated by up to 30\% in AD brains. Given that MT-3 contributes, among others, to detoxification and storage of heavy metals, regulation of $\mathrm{Cu}$ and $\mathrm{Zn}$ metabolism, and modulation of $\mathrm{A} \beta$ endocytosis of astrocytes (125), increasing MT-3 levels in AD has been explored as therapeutic strategy. In vivo studies demonstrated that effects of Zn-loaded MT-3 treatment in a mouse model for AD (Tg2576 mice) are inconsistent if MT-3 is injected subcutaneously. However, MT-3 injected intracerebroventricularly is able to ameliorate behavioral deficits and hippocampal impairments in APP/PS1 mice. In these mice, MT-3 treatment was also able to restore metal homeostasis, inhibit A $\beta$ aggregation, and reduce oxidative stress and neurodegeneration (125).

Another interesting treatment strategy is based on metal protein attenuating compounds (MPACs): Clioquinol (CQ) represents the prototypic MPAC. It is a small hydrophobic molecule that can cross the BBB and that has moderate affinity for metal ions. When administered to Tg2576 mice, a 49\% decrease of A $\beta$ in the brain of AD model mice compared to control mice was shown (126). In humans, oral CQ treatment for 36 weeks of severely affected AD patients was able to significantly prevent cognitive deterioration. Subsequent clinical studies of this compound were not pursued. However, PBT2, a highly soluble derivate of CQ (a second-generation MPAC), has been used first in APP/PS1 mice and then in human clinical trials (phase I and II). The results showed improved cognitive performance and reduced A $\beta$ load in the mouse model. A 12-week-long treatment of 78 patients with early AD showed that PBT2 is safe (127). Although the effects of PBT2 were inconsistent, executive dysfunction was significantly reduced in the patients. Several other metal chelators were engineered over the last years, and most of them are currently investigated for use in AD. Some of them have been shown to be effective at inhibiting $A \beta$-metal interactions both in vitro and in vivo. For example, it has been demonstrated that the normally insoluble $A \beta$ deposits of postmortem brain tissue from $\mathrm{AD}$ patients can be solubilized in aqueous media in the presence of specific $\mathrm{Cu}$ chelators (128).

Another promising approach is the delivery of metals directly to the brain using nanotechnological approaches. Polymeric g7-poly-lactide-co-glycolide (PLGA) nanoparticles (NPs) are able to cross the BBB and release metals within the brain. This system has been considered as a Trojan horse strategy to effectively deliver Zn to the brain with a low-toxicity profile (129). Three hours after ip injection of NPs, an increase of Zn levels in the brain and the increase of zinc-sensitive 
genes such as MT and Zn transporters were seen (130). The same pharmacological approach applied to APP23 mice, an animal model of AD, showed promising effects such as A $\beta$ dis-aggregation, a reduction of inflammation, and synapse stabilization (129). Thus, both redistribution of metals bound to A $\beta$ through MPACs and increase in metal levels that has dropped through trapping of metals in $A \beta$ deposits have beneficial effects. However, additional research is necessary to redefine time point of application, duration, and concentration of NP-based metal delivery.

\section{CONCLUSIONS AND FUTURE PERSPECTIVES}

In general, impaired biometal homeostasis and/or the accumulation of nonessential trace metals have significant effects, most prominently on proteotoxic stress, synapse function, oxidative stress, and inflammatory processes. Building on the metal-binding abilities of key proteins in $\mathrm{AD}$, brain imaging-based methods for the diagnosis of AD in humans have been, and are, currently developed. However, despite improving techniques for the detection of trace metals in the brain, re-establishing metal balances remains a difficult task. Initial studies using Zn ionophores have been promising and showed that targeting metal homeostasis in $\mathrm{AD}$ may be one of the most auspicious therapeutic strategies. However, new targeted and improved approaches are needed in the future.

Acknowledgments: The authors acknowledge the networking support by the COST Action TD1304 (Zinc-Net).

Conflict of interest: The authors declare no potential conflicts of interest with respect to research, authorship, and/or publication of this chapter.

Copyright and Permission Statement: To the best of our knowledge, the materials included in this chapter do not violate copyright laws. All original sources have been appropriately acknowledged and/or referenced. Where relevant, appropriate permissions have been obtained from the original copyright holder(s).

\section{REFERENCES}

1. Andreini C, Banci L, Bertini I, Rosato A. Counting the zinc-proteins encoded in the human genome. J Proteome Res. 2006;5(1):196-201. http://dx.doi.org/10.1021/pr05036lj

2. Maret W. Metallomics: The science of biometals and biometalloids. In: Arruda MAZ, editor. Metallomics: The science of biometals. New York: Springer; 2018. p. 1-20.

3. Bitanihirwe BK, Cunningham MG. Zinc: The brain's dark horse. Synapse. 2009;63(11):1029-49. http://dx.doi.org/10.1002/syn.20683

4. Grochowski C, Blicharska E, Krukow P, Jonak K, Maciejewski M, Szczepanek D, et al. Analysis of trace elements in human brain: Its aim, methods, and concentration levels. Front Chem. 2019;7:115. http://dx.doi.org/10.3389/fchem.2019.00115

5. Krebs N, Langkammer C, Goessler W, Ropele S, Fazekas F, Yen K, et al. Assessment of trace elements in human brain using inductively coupled plasma mass spectrometry. J Trace Elem Med Biol. 2014;28(1):1-7. http://dx.doi.org/10.1016/j.jtemb.2013.09.006 
6. Grabrucker AM, Ruozi B, Belletti D, Pederzoli F, Forni F, Vandelli MA, et al. Nanoparticle transport across the blood brain barrier. Tissue Barriers. 2016;4(1):e1153568. http://dx.doi.org/10.1080/2168 8370.2016.1153568

7. Baltaci AK, Yuce K. Zinc transporter proteins. Neurochem Res. 2018;43(3):517-30. http://dx.doi. org/10.1007/s1 1064-017-2454-y

8. Sensi SL, Granzotto A, Siotto M, Squitti R. Copper and zinc dysregulation in Alzheimer's disease. Trends Pharmacol Sci. 2018;39(12):1049-63. http://dx.doi.org/10.1016/j.tips.2018.10.001

9. Pfaender S, Grabrucker AM. Characterization of biometal profiles in neurological disorders. Metallomics. 2014;6(5):960-77. http://dx.doi.org/10.1039/C4MT00008K

10. Ziller A, Fraissinet-Tachet L. Metallothionein diversity and distribution in the tree of life: A multifunctional protein. Metallomics. 2018;10(11):1549-59. http://dx.doi.org/10.1039/C8MT00165K

11. Brown DR. $\alpha$-Synuclein as a ferrireductase. Biochem Soc Trans. 2013;41(6):1513-17. http://dx.doi. org/10.1042/BST20130130

12. Roberts BR, Ryan TM, Bush AI, Masters CL, Duce JA. The role of metallobiology and amyloid- $\beta$ peptides in Alzheimer's disease. J Neurochem. 2012;120(Suppl. 1):149-166. http://dx.doi. org/10.1111/j.1471-4159.2011.07500.x

13. Grabrucker AM, Schmeisser MJ, Udvardi PT, Arons M, Schoen M, Woodling NS, et al. Amyloid beta protein-induced zinc sequestration leads to synaptic loss via dysregulation of the ProSAP2/Shank3 scaffold. Mol Neurodegener. 2011;6:65. http://dx.doi.org/10.1186/1750-1326-6-65

14. Strozyk D, Launer LJ, Adlard PA, Cherny RA, Tsatsanis A, Volitakis I, et al. Zinc and copper modulate Alzheimer Abeta levels in human cerebrospinal fluid. Neurobiol Aging. 2009;30(7):1069-77. http:// dx.doi.org/10.1016/j.neurobiolaging.2007.10.012

15. Cornett CR, Markesbery WR, Ehmann WD. Imbalances of trace elements related to oxidative damage in Alzheimer's disease brain. Neurotoxicology. 1998;19(3):339-45.

16. Perry G, Cash AD, Smith MA. Alzheimer disease and oxidative stress. J Biomed Biotechnol. 2002;2(3):120-3. http://dx.doi.org/10.1155/S1110724302203010

17. Huang WJ, Zhang X, Chen WW. Role of oxidative stress in Alzheimer's disease. Biomed Rep. 2016;4(5):519-22. http://dx.doi.org/10.3892/br.2016.630

18. Halliwell B. Reactive oxygen species and the central nervous system. J Neurochem. 1992;59(5):1609-23. http://dx.doi.org/10.1111/j.1471-4159.1992.tb10990.x

19. Maret W. The redox biology of redox-inert zinc ions. Free Radic Biol Med. 2019;134:311-26. http:// dx.doi.org/10.1016/j.freeradbiomed.2019.01.006

20. Cabrera ÁJ. Zinc, aging, and immunosenescence: An overview. Pathobiol Aging Age Relat Dis. 2015;5:25592. http://dx.doi.org/10.3402/pba.v5.25592

21. Prasad AS, Fitzgerald JT, Hess JW, Kaplan J, Pelen F, Dardenne M. Zinc deficiency in elderly patients. Nutrition. 1993;9(3):218-24.

22. Haase H, Rink L. The immune system and the impact of zinc during aging. Immun Ageing. 2009;6:9. http://dx.doi.org/10.1186/1742-4933-6-9

23. Hagmeyer S, Haderspeck JC, Grabrucker AM. Behavioral impairments in animal models for zinc deficiency. Front Behav Neurosci. 2014;8:443. http://dx.doi.org/10.3389/fnbeh.2014.00443

24. Greenough MA, Volitakis I, Li QX, Laughton K, Evin G, Ho M, et al. Presenilins promote the cellular uptake of copper and zinc and maintain copper chaperone of SODl-dependent copper/zinc superoxide dismutase activity. J Biol Chem. 2011;286(11):9776-86. http://dx.doi.org/10.1074/jbc. M110.163964

25. Walsh DM, Minogue AM, Sala Frigerio C, Fadeeva JV, Wasco W, Selkoe DJ. The APP family of proteins: Similarities and differences. Biochem Soc Trans. 2007;35(Pt 2):416-20. http://dx.doi.org/10.1042/ BST0350416

26. Bonda DJ, Lee HG, Blair JA, Zhu X, Perry G, Smith MA. Role of metal dyshomeostasis in Alzheimer's disease. Metallomics. 2011;3(3):267-70. http://dx.doi.org/10.1039/c0mt00074d

27. Kepp KP. Bioinorganic chemistry of Alzheimer's disease. Chem Rev. 2012;112(10):5193-239. http:// dx.doi.org/10.1021/cr300009x

28. Dahms SO, Könnig I, Roeser D, Gührs KH, Mayer MC, Kaden D, et al. Metal binding dictates conformation and function of the amyloid precursor protein (APP) E2 domain. J Mol Biol. 2012;416(3): 438-52. http://dx.doi.org/10.1016/j.jmb.2011.12.057 
29. Barnham KJ, McKinstry WJ, Multhaup G, Galatis D, Morton CJ, Curtain CC, et al. Structure of the Alzheimer's disease amyloid precursor protein copper binding domain. A regulator of neuronal copper homeostasis. J Biol Chem. 2003;278(19):17401-7. http://dx.doi.org/10.1074/jbc. M300629200

30. Spoerri L, Vella LJ, Pham CL, Barnham KJ, Cappai R. The amyloid precursor protein copper binding domain histidine residues 149 and 151 mediate APP stability and metabolism. J Biol Chem. 2012;287(32):26840-53. http://dx.doi.org/10.1074/jbc.M112.355743

31. Acevedo KM, Hung YH, Dalziel AH, Li QX, Laughton K, Wikhe K, et al. Copper promotes the trafficking of the amyloid precursor protein. J Biol Chem. 2011;286(10):8252-62. http://dx.doi.org/10.1074/ jbc.M110.128512

32. Bellingham SA, Coleman LA, Masters CL, Camakaris J, Hill AF. Regulation of prion gene expression by transcription factors SP1 and metal transcription factor-1. J Biol Chem. 2009;284(2):1291-301. http://dx.doi.org/10.1074/jbc.M804755200

33. Bush AI, Multhaup G, Moir RD, Williamson TG, Small DH, Rumble B, et al. A novel zinc(II) binding site modulates the function of the beta A4 amyloid protein precursor of Alzheimer's disease. J Biol Chem. 1993;268(22):16109-12.

34. Bush AI, Pettingell WH, Multhaup G, d Paradis M, Vonsattel JP, Gusella JF, et al. Rapid induction of Alzheimer A beta amyloid formation by zinc. Science. 1994;265(5177):1464-7. http://dx.doi. org/10.1126/science.8073293

35. Scheuermann S, Hambsch B, Hesse L, Stumm J, Schmidt C, Beher D, et al. Homodimerization of amyloid precursor protein and its implication in the amyloidogenic pathway of Alzheimer's disease. J Biol Chem. 2001;276(36):33923-9. http://dx.doi.org/10.1074/jbc.M105410200

36. Rogers JT, Randall JD, Cahill CM, Eder PS, Huang X, Gunshin H, et al. An iron-responsive element type II in the 5'-untranslated region of the Alzheimer's amyloid precursor protein transcript. J Biol Chem. 2002;277(47):45518-28. http://dx.doi.org/10.1074/jbc.M207435200

37. Venti A, Giordano T, Eder P, Bush AI, Lahiri DK, Greig NH, et al. The integrated role of desferrioxamine and phenserine targeted to an iron-responsive element in the APP-mRNA 5'-untranslated region. Ann N Y Acad Sci. 2004;1035:34-48. http://dx.doi.org/10.1196/annals.1332.003

38. Duce JA, Tsatsanis A, Cater MA, James SA, Robb E, Wikhe K, et al. Iron-export ferroxidase activity of $\beta$-amyloid precursor protein is inhibited by zinc in Alzheimer's disease. Cell. 2010;142(6):857-67. http://dx.doi.org/10.1016/j.cell.2010.08.014

39. Cross JB, Duca JS, Kaminski JJ, Madison VS. The active site of a zinc-dependent metalloproteinase influences the computed $\mathrm{pK}(\mathrm{a})$ of ligands coordinated to the catalytic zinc ion. J Am Chem Soc. 2002;124(37):11004-7. http://dx.doi.org/10.1021/ja0201810

40. Angeletti B, Waldron KJ, Freeman KB, Bawagan H, Hussain I, Miller CC, et al. BACEl cytoplasmic domain interacts with the copper chaperone for superoxide dismutase-1 and binds copper. J Biol Chem. 2005;280(18):17930-7. http://dx.doi.org/10.1074/jbc.M412034200

41. Park IH, Jung MW, Mori H, Mook-Jung I. Zinc enhances synthesis of presenilin 1 in mouse primary cortical culture. Biochem Biophys Res Commun. 2001;285(3):680-8. http://dx.doi.org/10.1006/ bbrc. 2001.5243

42. Savelieff MG, Lee S, Liu Y, Lim MH. Untangling amyloid- $\beta$, tau, and metals in Alzheimer's disease. ACS Chem Biol. 2013;8(5):856-65. http://dx.doi.org/10.1021/cb400080f

43. Johnstone EM, Chaney MO, Norris FH, Pascual R, Little SP. Conservation of the sequence of the Alzheimer's disease amyloid peptide in dog, polar bear and five other mammals by cross-species polymerase chain reaction analysis. Brain Res Mol Brain Res. 1991;10(4):299-305. http://dx.doi. org/10.1016/0169-328X(91)90088-F

44. Gaggelli E, Grzonka Z, Kozłowski H, Migliorini C, Molteni E, Valensin D, et al. Structural features of the $\mathrm{Cu}(\mathrm{II})$ complex with the rat Abeta(1-28) fragment. Chem Commun (Camb). 2008;(3):341-3. http://dx.doi.org/10.1039/B713453C

45. Lovell MA, Robertson JD, Teesdale WJ, Campbell JL, Markesbery WR. Copper, iron and zinc in Alzheimer's disease senile plaques. J Neurol Sci. 1998;158(1):47-52. http://dx.doi.org/10.1016/ S0022-510X(98)00092-6

46. Cuajungco MP, Lees GJ. Zinc and Alzheimer's disease: Is there a direct link? Brain Res Brain Res Rev. 1997;23(3):219-36. http://dx.doi.org/10.1016/S0165-0173(97)00002-7 
47. Huang X, Atwood CS, Moir RD, Hartshorn MA, Vonsattel JP, Tanzi RE, et al. Zinc-induced Alzheimer's Abetal-40 aggregation is mediated by conformational factors. J Biol Chem. 1997;272(42):26464-70. http://dx.doi.org/10.1074/jbc.272.42.26464

48. Kim AC, Lim S, Kim YK. Metal ion effects on A $\beta$ and tau aggregation. Int J Mol Sci. 2018;19(1):128. http://dx.doi.org/10.3390/ijms19010128

49. Minicozzi V, Stellato F, Comai M, Dalla Serra M, Potrich C, Meyer-Klaucke W, et al. Identifying the minimal copper- and zinc-binding site sequence in amyloid-beta peptides. J Biol Chem. 2008;283(16):10784-92. http://dx.doi.org/10.1074/jbc.M707109200

50. Cherny RA, Atwood CS, Xilinas ME, Gray DN, Jones WD, McLean CA, et al. Treatment with a copperzinc chelator markedly and rapidly inhibits beta-amyloid accumulation in Alzheimer's disease transgenic mice. Neuron. 2001;30(3):665-76. http://dx.doi.org/10.1016/S0896-6273(01)00317-8

51. Bush AI. Metal complexing agents as therapies for Alzheimer's disease. Neurobiol Aging. 2002;23(6):1031-8. http://dx.doi.org/10.1016/S0197-4580(02)00120-3

52. Telling ND, Everett J, Collingwood JF, Dobson J, van der Laan G, Gallagher JJ, et al. Iron biochemistry is correlated with amyloid plaque morphology in an established mouse model of Alzheimer's disease. Cell Chem Biol. 2017;24(10):1205-1215.e3. http://dx.doi.org/10.1016/j.chembiol.2017.07.014

53. van Duijn S, Bulk M, van Duinen SG, Nabuurs RJA, van Buchem MA, van der Weerd L, et al. Cortical iron reflects severity of Alzheimer's disease. J Alzheimers Dis. 2017;60(4):1533-45.

54. Tong Y, Yang H, Tian X, Wang H, Zhou T, Zhang S, et al. High manganese, a risk for Alzheimer's disease: High manganese induces amyloid- $\beta$ related cognitive impairment. J Alzheimers Dis. 2014;42(3):865-78. http://dx.doi.org/10.3233/JAD-140534

55. Neumann M, Diekmann S, Bertsch U, Vanmassenhove B, Bogerts B, Kretzschmar HA. Novel G335V mutation in the tau gene associated with early onset familial frontotemporal dementia. Neurogenetics. 2005;6(2):91-5. http://dx.doi.org/10.1007/s10048-005-0210-y

56. Bunker JM. Modulation of microtubule dynamics by tau in living cells: Implications for development and neurodegeneration. Mol Biol Cell. 2004;15(6):2720-8. http://dx.doi.org/10.1091/mbc. e04-01-0062

57. Ittner LM, Ke YD, Delerue F, Bi M, Gladbach A, van Eersel J, Götz J. Dendritic function of tau mediates amyloid- $\beta$ toxicity in Alzheimer's disease mouse models. Cell. 2010;142(3):387-97. http://dx.doi. org/10.1016/j.cell.2010.06.036

58. Weingarten MD, Lockwood AH, Hwo SY, Kirschner MW. A protein factor essential for microtubule assembly. Proc Natl Acad Sci U S A. 1975;72(5):1858-62. http://dx.doi.org/10.1073/pnas.72.5.1858

59. Fontaine SN, Sabbagh JJ, Baker J, Martinez-Licha AD, Chad AD. Cellular factors modulating the mechanism of tau protein aggregation. Cell Mol Life Sci. 2015;72(10):1863-79. http://dx.doi. org/10.1007/s00018-015-1839-9

60. Cleveland DW, Hwo SY, Kirschner MW. Purification of tau, a microtubule-associated protein that induces assembly of microtubules from purified tubulin. J Mol Biol. 1977;116(2):207-225. http:// dx.doi.org/10.1016/0022-2836(77)90213-3

61. Mandelkow EM, Mandelkow E. Biochemistry and cell biology of tau protein in neurofibrillary degeneration. Cold Spring Harb Perspect Med. 2012;2(7):a006247. http://dx.doi.org/10.1101/cshperspect.a006247

62. Mukrasch MD, Bibow S, Korukottu J, Jeganathan S, Biernat J, Griesinger C, Zweckstetter M. Structural polymorphism of 441-residue Tau at single residue resolution. PLoS Biol. 2009;7(2):e34. http:// dx.doi.org/10.1371/journal.pbio. 1000034

63. Hirokawa N, Shiomura Y, Okabe S. Tau proteins: The molecular structure and mode of binding on microtubules. J Cell Biol. 1988;107(4):1449-59. http://dx.doi.org/10.1083/jcb.107.4.1449

64. Brandt R, Léger J, Lee G. Interaction of tau with the neural plasma membrane mediated by tau's amino-terminal projection domain. J Cell Biol. 1995;131(5):1327-40. http://dx.doi.org/10.1083/ jcb.131.5.1327

65. Sergeant N, Bretteville A, Hamdane M, Caillet-Boudin ML, Grognet P, Bombois S, Buée L. Biochemistry of Tau in Alzheimer's disease and related neurological disorders. Expert Rev Proteomics. 2008;5(2):207-24. http://dx.doi.org/10.1586/14789450.5.2.207 
66. Sergeant N, Delacourte A, Buée L. Tau protein as a differential biomarker of tauopathies. Biochim Biophys Acta. 2005;1739(2-3):179-97. http://dx.doi.org/10.1016/j.bbadis.2004.06.020

67. Cox K, Combs B, Abdelmesih B, Morfini G, Brady ST, Kanaan NM. Analysis of isoform-specific tau aggregates suggests a common toxic mechanism involving similar pathological conformations and axonal transport inhibition. Neurobiol Aging. 2016;47:113-26. http://dx.doi.org/10.1016/j. neurobiolaging.2016.07.015

68. Sayre LM, Perry G, Harris PLR, Liu Y, Schubert KA, Smith MA. In situ oxidative catalysis by neurofibrillary tangles and senile plaques in Alzheimer's disease: A central role for bound transition metals. J Neurochem. 2000;74(1):270-279. http://dx.doi.org/10.1046/j.1471-4159.2000.0740270.x

69. Mo ZY, Zhu YZ, Zhu HL, Fan JB, Chen J, Liang Y. Low micromolar zinc accelerates the fibrillization of human Tau via bridging of Cys-291 and Cys-322. J Biol Chem. 2009;284(50):34648-57. http:// dx.doi.org/10.1074/jbc.M109.058883

70. Kim I, Park EJ, Seo J, Ko SJ, Lee J, Kim CH. Zinc stimulates tau S214 phosphorylation by the activation of Raf/mitogen-activated protein kinase-kinase/extracellular signal-regulated kinase pathway. Neuro Rep. 2011;22(16):839-44. http://dx.doi.org/10.1097/WNR.0b013e32834c0a2d

71. Xiong Y, Jing XP, Zhou XW, Wang XL, Yang Y, Sun XY, Wang JZ. Zinc induces protein phosphatase 2A inactivation and tau hyperphosphorylation through Src dependent PP2A (tyrosine 307) phosphorylation. Neurobiol Aging. 2013;34(3):745-56. http://dx.doi.org/10.1016/j. neurobiolaging.2012.07.003

72. Huang Y, Wu Z, Cao Y, Lang M., Lu B, Zhou B. Zinc binding directly regulates tau toxicity independent of tau hyperphosphorylation. Cell Rep. 2014;8(3):831-42. http://dx.doi.org/10.1016/j. celrep.2014.06.047

73. Li X, Du X, Ni J. Zn ${ }^{2+}$ aggravates tau aggregation and neurotoxicity. Int J Mol Sci. 2019;20(3):pii: E487. http://dx.doi.org/10.3390/ijms20030487

74. Shafiei SS, Guerrero-Muñoz MJ, Castillo-Carranza DL. Tau oligomers: Cytotoxicity, propagation, and mitochondrial damage. Front Aging Neurosci. 2017;9:83. http://dx.doi.org/10.3389/ fnagi.2017.00083

75. CristóvãoJS, Santos R, Gomes CM. Metals and neuronal metal binding proteins implicated in Alzheimer's disease. Oxid Med Cell Longevity. 2016;(1):1-13. http://dx.doi.org/10.1155/2016/9812178

76. Crouch PJ, Hung LW, Adlard PA, Cortes M, Lal V, Filiz G, et al. Increasing Cu bioavailability inhibits abetaoligomers and tau phosphorylation. Proc Natl Acad Sci. 2009;106(2):381-6. http://dx.doi. org/10.1073/pnas.0809057106

77. Voss K, Harris C, Ralle M, Duffy M, Murchison C, Quinn JF. Modulation of tau phosphorylation by environmental copper. Trans Neurodegener. 2014;3(1):24. http://dx.doi.org/10.1186/2047-9158-3-24

78. Kitazawa M, Cheng D, Laferla FM. Chronic copper exposure exacerbates both amyloid and tau pathology and selectively dysregulates cdk5 in a mouse model of AD. J Neurochem. 2009;108(6):1550-60. http://dx.doi.org/10.1111/j.1471-4159.2009.05901.x

79. Soragni A, Zambelli B, Mukrasch MD, Biernat J, Jeganathan S, Griesinger C, et al. Structural characterization of binding of $\mathrm{Cu}$ (II) to tau protein. Biochemistry. 2008;47(41):10841-51. http://dx.doi. org/10.1021/bi8008856

80. Ma Q, Li Y, Du J, Liu H, Kanazawa K, Nemoto T, et al. Copper binding properties of a tau peptide associated with Alzheimer's disease studied by CD, NMR, and MALDI-TOF MS. Peptides. 2006;27(4):841-9. http://dx.doi.org/10.1016/j.peptides.2005.09.002

81. Zhou LX, Du JT, Zeng ZY, Wu WH, Zhao YF, Kanazawa K, et al. Copper (II) modulates in vitro aggregation of a tau peptide. Peptides. 2007;28(11):2229-34. http://dx.doi.org/10.1016/j. peptides.2007.08.022

82. Su XY, Wu WH, Huang ZP, Hu J, Lei P, Yu CH, et al. Hydrogen peroxide can be generated by tau in the presence of $\mathrm{Cu}(\mathrm{II})$. Biochem Biophys Res Commun. 2007;358(2):661-5. http://dx.doi.org/10.1016/j. bbrc.2007.04.191

83. Ma Q, Li Y, Du J, Kanazawa K, Nemoto T, Nakanishi H, et al. Binding of copper (II) ion to an Alzheimer's tau peptide as revealed by MALDI-TOF MS, CD, and NMR. Biopolymers. 2005;79(2): 74-85. http://dx.doi.org/10.1002/bip.20335 
84. Andrási, E, Farkas É, Scheibler H, Réffy A, Bezúr L. Al, Zn, Cu, Mn and Fe levels in brain in Alzheimer's disease. Arch Gerontol Geriatr. 1995;21(1):89-97. http://dx.doi.org/10.1016/0167-4943(95)00643-Y

85. Smith MA, Harris PLR, Sayre LM, Perry G. Iron accumulation in Alzheimer disease is a source of redoxgenerated free radicals. Proc Natl Acad Sci U S A. 1997;94(18):9866-8. http://dx.doi.org/10.1073/ pnas.94.18.9866

86. Ahmadi S, Zhu S, Sharma R, Wilson DJ, Kraatz H. Interaction of metal ions with tau protein. The case for a metal-mediated tau aggregation. J Inorganic Biochem. 2018;194:44-51. http://dx.doi. org/10.1016/j.jinorgbio.2019.02.007

87. Rao SS, Adlard PA. Untangling tau and iron: Exploring the interaction between iron and tau in neurodegeneration. Front Mol Neurosci. 2018;11:276. http://dx.doi.org/10.3389/fnmol.2018.00276

88. Guo C, Wang P, Zhong ML, Wang T, Huang XS, Li JY, Wang ZY. Deferoxamine inhibits iron induced hippocampal tau phosphorylation in the Alzheimer transgenic mouse brain. Neurochem Int. 2013;62(2):165-72. http://dx.doi.org/10.1016/j.neuint.2012.12.005

89. Andrási E, Páli N, Molnár Z, Kösel S. Brain aluminum, magnesium and phosphorus contents of control and Alzheimer-diseased patients. J Alzheimers Dis. 2005;7(4):273-84. http://dx.doi.org/10.3233/ JAD-2005-7402

90. Xu ZP, Li L, Bao J, Wang ZH, Zeng J, Liu EJ, Wang JZ. Magnesium protects cognitive functions and synaptic plasticity in streptozotocin-induced sporadic Alzheimer's model. PLoS One. 2014;9(9):e108645. http://dx.doi.org/10.1371/journal.pone.0108645

91. Ramos P, Santos A, Pinto NR, Mendes R, Magalhães T, Almeida A. Iron levels in the human brain: A post-mortem study of anatomical region differences and age-related changes. J Trace Elements Med Biol. 2014;28(1):13-17. http://dx.doi.org/10.1016/j.jtemb.2013.08.001

92. Cai T, Che H, Yao T, Chen Y, Huang C, Zhang LW. Manganese induces Tau hyperphosphorylation through the activation of ERK MAPK pathway in PC12 cells. Toxicol Sci. 2011;119(1):169-77. http:// dx.doi.org/10.1093/toxsci/kfq308

93. Rankin CA, Sun Q, Gamblin TC. Tau phosphorylation by GSK-3ß promotes tangle-like filament morphology. Mol Neurodegener. 2007;2:12. http://dx.doi.org/10.1186/1750-1326-2-12

94. Liu F, Li B, Tung EJ, Grundke-Iqbal I, Iqbal K, Gong C. X. Site-specific effects of tau phosphorylation on its microtubule assembly activity and self-aggregation. Eur J Neurosci. 2007;26(12):3429-36. http://dx.doi.org/10.1111/j.1460-9568.2007.05955.x

95. Nübling G, Bader B, Levin J, Hildebrandt J, Kretzschmar H, Giese A. Synergistic influence of phosphorylation and metal ions on tau oligomer formation and coaggregation with $\alpha$-synuclein at the single molecule level. Mol Neurodegener. 2012;7:35. http://dx.doi.org/10.1186/1750-1326-7-35

96. Klatzo I, Wisniewski H, Streicher E. Experimental production of neurofibrillary degeneration: I. Light microscopic observations. J Neuropathol Exp Neurol. 1965;24(2):187-99. http://dx.doi. org/10.1097/00005072-196504000-00002

97. Walton JR. An aluminum-based rat model for Alzheimer's disease exhibits oxidative damage, inhibition of PP2A activity, hyperphosphorylated tau, and granulovacuolar degeneration. J Inorganic Biochem. 2007;101(9):1275-84. http://dx.doi.org/10.1016/j.jinorgbio.2007.06.001

98. Budimir A. Metal ions, Alzheimer's disease and chelation therapy. Acta Pharm. 2011;61:1-14. http:// dx.doi.org/10.2478/v10007-011-0006-6

99. Panayi AE, Spyrou NM, Iversen BS, White MA, Part P. Determination of cadmium and zinc in Alzheimer's brain tissue using inductively coupled plasma mass spectrometry. J Neurol Sci. 2002;195(1):1-10. http://dx.doi.org/10.1016/S0022-510X(01)00672-4

100. Notarachille G, Arnesano F, Calò V, Meleleo D. Heavy metals toxicity: Effect of cadmium ions on amyloid beta protein 1-42. Possible implications for Alzheimer's disease. Bio Metals. 2014;27(2):371-88. http://dx.doi.org/10.1007/s10534-014-9719-6

101. Jiang LF, Yao TM, Zhu ZL, Wang C, Ji LN. Impacts of Cd (II) on the conformation and selfaggregation of Alzheimer's tau fragment corresponding to the third repeat of microtubulebinding domain. Biochim Biophys Acta. 2007;1774(11):1414-21. http://dx.doi.org/10.1016/j. bbapap.2007.08.014

102. del Pino J, Zeballos G, Anadón MJ, Moyano P, Díaz MJ, García JM, et al. Cadmium-induced cell death of basal forebrain cholinergic neurons mediated by muscarinic Ml receptor blockade, increase in GSK-3 $\beta$ enzyme, $\beta$-amyloid and tau protein levels. Arch Toxicol. 2016;90:1081-92. http://dx.doi. org/10.1007/s00204-015-1540-7 
103. Bihaqi SW, Bahmani A, Adem A, Zawia NH. Infantile postnatal exposure to lead (Pb) enhances tau expression in the cerebral cortex of aged mice: Relevance to AD. Neuro Toxicol. 2014;44:114-20. http://dx.doi.org/10.1016/j.neuro.2014.06.008

104. Cedrola S, Guzzi GP, Ferrari D, Gritti A, Vescovi AL, Pendergrass JC, et al. Inorganic mercury changes the fate of murine CNS stem cells. FASEB J. 2003;17(8):869-71. http://dx.doi.org/10.1096/ fj.02-049lfje

105. Mutter J, Naumann J, Sadaghiani C, Schneider R, Walach H. Alzheimer disease: Mercury as pathogenetic factor and apolipoprotein E as a moderator. Neuro Endocrinol Lett. 2004;25(5):331-9.

106. BusciglioJ, Lorenzo A, YehJ, Yankner BA. $\beta$-Amyloid fibrils induce tau phosphorylation and loss of microtubule binding. Neuron. 1995;14(4):879-88. http://dx.doi.org/10.1016/0896-6273(95)90232-5

107. Libermann TA, Baltimore D. Activation of interleukin-6 gene expression through the NF-kappa B transcription factor. Mol Cell Biol. 1990;10(5):2327-34. http://dx.doi.org/10.1128/MCB.10.5.2327

108. Liu MJ, Bao S, Gálvez-Peralta M, Pyle CJ, Rudawsky AC, Pavlovicz RE, et al. ZIP8 regulates host defense through zinc-mediated inhibition of NF-kB. Cell Rep. 2013;3(2):386-400. http://dx.doi. org/10.1016/j.celrep.2013.01.009

109. Saco T, Parthasarathy PT, Cho Y, Lockey RF, Kolliputi N. Inflammasome: A new trigger of Alzheimer's disease. Front Aging Neurosci. 2014;6:80. http://dx.doi.org/10.3389/fnagi.2014.00080

110. Prinz M, Priller J, Sisodia SS, Ransohoff RM. Heterogeneity of CNS myeloid cells and their roles in neurodegeneration. Nat Neurosci. 2011;14(10):1227-35. http://dx.doi.org/10.1038/nn.2923

111. Deigendesch N, Zychlinsky A, Meissner F. Copper regulates the canonical NLRP3 inflammasome. J Immunol. 2018;200(5):1607-17. http://dx.doi.org/10.4049/jimmunol.1700712

112. Summersgill H, England H, Lopez-Castejon G, Lawrence CB, Luheshi NM, Pahle J, et al. Zinc depletion regulates the processing and secretion of IL-1 $\beta$. Cell Death Dis. 2014;5:e1040. http://dx.doi. org/10.1038/cddis.2013.547

113. Cristóvão JS, Morris VK, Cardoso I, Leal SS, Martínez J, Botelho HM, et al. The neuronal S100B protein is a calcium-tuned suppressor of amyloid- $\beta$ aggregation. Sci Adv. 2018;4(6):eaaq1702. http:// dx.doi.org/10.1126/sciadv.aaq1702

114. Hagmeyer S, Cristóvão JS, Mulvihill JJE, Boeckers TM, Gomes CM, Grabrucker AM. Zinc binding to $\mathrm{S} 100 \mathrm{~B}$ affords regulation of trace metal homeostasis and excitotoxicity in the brain. Front Mol Neurosci. 2017;10:456. http://dx.doi.org/10.3389/fnmol.2017.00456

115. Donato R, Cannon BR, Sorci G, Riuzzi F, Hsu K, Weber DJ, et al. Functions of S100 proteins. Curr Mol Med. 2013;13(1):24-57. http://dx.doi.org/10.2174/156652413804486214

116. Swindell WR, Johnston A, Xing X, Little A, Robichaud P, Voorhees JJ, et al. Robust shifts in S100a9 expression with aging: A novel mechanism for chronic inflammation. Sci Rep. 2013;3:1215. http:// dx.doi.org/10.1038/srep01215

117. Grabrucker AM, Knight MJ, Proepper C, Bockmann J, Joubert M, Rowan M, et al. Concerted action of zinc and ProSAP/Shank in synaptogenesis and synapse maturation. EMBO J. 2011;30(3):569-81. http://dx.doi.org/10.1038/emboj.2010.336

118. Roselli F, Hutzler P, Wegerich Y, Livrea P, Almeida OF. Disassembly of shank and homer synaptic clusters is driven by soluble beta-amyloid(1-40) through divergent NMDAR-dependent signalling pathways. PLoS One. 2009;4(6):e6011. http://dx.doi.org/10.1371/journal.pone.0006011

119. Gong Y, Lippa CF, Zhu J, Lin Q, Rosso AL. Disruption of glutamate receptors at Shank-postsynaptic platform in Alzheimer's disease. Brain Res. 2009;1292:191-8. http://dx.doi.org/10.1016/j. brainres.2009.07.056

120. Adlard PA, Parncutt JM, Finkelstein DI, Bush AI. Cognitive loss in zinc transporter-3 knockout mice: A phenocopy for the synaptic and memory deficits of Alzheimer's disease? J Neurosci. 2010;30(5):1631-6. http://dx.doi.org/10.1523/JNEUROSCI.5255-09.2010

121. Paoletti P, Ascher P, Neyton J. High-affinity zinc inhibition of NMDA NR1-NR2A receptors. J Neurosci. 1997;17(15):5711-25. http://dx.doi.org/10.1523/JNEUROSCI.17-15-05711.1997

122. Johanssen T, Suphantarida N, Donnelly PS, Liu XM, Petrou S, Hill AF, et al. PBT2 inhibits glutamate-induced excitotoxicity in neurons through metal-mediated preconditioning. Neurobiol Dis. 2015;81:176-85. http://dx.doi.org/10.1016/j.nbd.2015.02.008

123. Braidy N, Poljak A, Marjo C, Rutlidge H, Rich A, Jayasena T, et al. Metal and complementary molecular bioimaging in Alzheimer's disease. Front Aging Neurosci. 2014;6:138. http://dx.doi.org/10.3389/ fnagi.2014.00138 
124. Bourassa MW, Miller LM. Metal imaging in neurodegenerative diseases. Metallomics. 2012;4(8): 721-38. http://dx.doi.org/10.1039/c2mt20052j

125. Xu W, Xu Q, Cheng H, Tan X. The efficacy and pharmacological mechanism of Zn7MT3 to protect against Alzheimer's disease. Sci Rep. 2017;7(1):13763. http://dx.doi.org/10.1038/s41598-017-12800-x

126. Bush AI. The metallobiology of Alzheimer's disease. Trends Neurosci. 2003;26(4):207-14. http:// dx.doi.org/10.1016/S0166-2236(03)00067-5

127. Sampson EL, Jenagaratnam L, McShane R. Metal protein attenuating compounds for the treatment of Alzheimer's dementia. Cochrane Database Syst Rev. 2012;(5):CD005380. http://dx.doi. org/10.1002/14651858.CD005380.pub4

128. Cherny RA, Legg JT, McLean CA, Fairlie DP, Huang X, Atwood CS, et al. Aqueous dissolution of Alzheimer's disease Abeta amyloid deposits by biometal depletion. J Biol Chem. 1999; 274(33): 23223-8. http://dx.doi.org/10.1074/jbc.274.33.23223

129. Vilella A, Belletti D, Sauer AK, Hagmeyer S, Sarowar T, Masoni M, et al. Reduced plaque size and inflammation in the APP23 mouse model for Alzheimer's disease after chronic application of polymeric nanoparticles for CNS targeted zinc delivery. J Trace Elem Med Biol. 2018;49:210-21. http:// dx.doi.org/10.1016/j.jtemb.2017.12.006

130. Chhabra R, Ruozi B, Vilella A, Belletti D, Mangus K, Pfaender S, et al. Application of polymeric nanoparticles for CNS targeted zinc delivery in vivo. CNS Neurol Disord Drug Targets. 2015;14(8):1041-53. http://dx.doi.org/10.2174/1871527314666150821111455 